\title{
Determinants of change in the duration of ice phenomena on the Vistula River in Toruń
}

\author{
Bogusław Pawłowski
}

Department of Hydrology and Water Management, Faculty of Earth Sciences, Nicolaus Copernicus University, ul. Lwowska 1, 87-100 Toruń, Poland. E-mail: bogus@umk.pl

\begin{abstract}
Winter season temperatures are becoming warmer. However, the transformation of the ice regime on the Vistula River in Torun has also been affected by river engineering. In particular, the construction and operation of the Włocławek Dam had a significant impact on ice processes. The article presents the results of an analysis determining the contribution of natural and anthropogenic factors to the duration of ice phenomena and ice cover on the Vistula River in the city of Torun. Compared to the end of the nineteenth century, there has been a reduction in the duration of ice phenomena from 88 to 53 days and of ice cover from 40 to 7 days (in the period of 1882-2011). The article compares the duration of ice cover and winter temperature in three different periods: before the completion of river engineering works (1882-1907); for the controlled river (1908-1969), and for the controlled river with the Włocławek Dam upstream of Torun (1970-2011). The results showed a significant role of these anthropogenic factors in the changes of the ice cover duration on the Vistula River in Torun.
\end{abstract}

Keywords: Ice phenomena; Vistula River; Natural factor; Human impact.

\section{INTRODUCTION}

Ice is present during a part of the year on many rivers of cold and temperate regions of the globe. Though largely ignored in hydrological literature, river ice has serious hydrologic impacts, including extreme flood events caused by ice jams, interference with transportation and energy production, low winter flows and associated ecological and water quality consequences. A significant number of the rivers in the Northern Hemisphere are annually affected by river ice. Two economic sectors that are most likely to be affected by climate-induced changes in river ice are transportation and hydropower generation where ice creates a host of difficulties for the operation of hydropower facilities (Prowse and Beltaos, 2002).

Over the past 150 years, significant global temperature change has been observed. In Germany, the mean temperature at 266 climate stations rose by $0.9^{\circ} \mathrm{C}$ from 1951 to 2006 (Hattermann et al., 2013). In particular, warming has affected the winter half-year in the northern hemisphere. Land regions have warmed faster than the oceans (http://www.ipcc.ch/ publications_and_data/ar4/syr/en/spms $1 . h t m l)$. The changing temperature of the winter season is accompanied by changes in the ice regime of rivers and lakes. Ice cover is one of the most important factors indicating winter temperature changes (Magnuson et al., 2000; Marszelewski and Skowron, 2006). The duration of ice cover in rivers in the Baltic region has declined from 27.4 to 19 days during the past 30 years as a function of meteorological conditions and global climate change (Klavins et al., 2009). These changes confirm the strong connection between the period of ice cover, the duration of ice phenomena, the mean value of air temperature in the winter season and the NDD (Negative Degree Day - the total of all average daily negative air temperatures recorded in the winter season - or socalled cold sum). River ice regimes have been observed to be related with the North Atlantic Oscillation - NAO (Hurrell, 1995). A trend towards shortening of the period of ice cover is not common throughout the entire northern hemisphere. Russian authors have found that the period of ice cover remains unchanged on rivers where the average elevation of the catch- ment exceeds $1500 \mathrm{~m}$ above sea level. This phenomenon was observed in the second half of the twentieth century in the upper part of the Yenisei basin (Paromov and Shantykowa, 2010). Earlier occurrence of autumn freezing and increase in the duration of ice cover (1930-1990) was found for some of the rivers of eastern Siberia (Smith, 2000). This applies, of course, to rivers where there is no influence of factors related to human activity.

Anthropogenic effects on rivers, including river engineering, hydropower use, and water pollution, not only change bed morphology and/or water quality but also affect the river ice regime. The length of the ice-affected season and the relative frequency of ice appearance might change due to anthropogenic activities. Moreover, anthropogenically induced changes may vastly exceed climatic effects. Anthropogenic impacts could exaggerate or hide natural trends in the river ice regime if they operate either in the same or opposite direction as the natural forces. Temperature rise alone is able to cause changes in river ice regime, but some studies highlight that anthropogenic interventions interfered with climatic triggers and significantly modified river ice regimes. The corresponding rising trend in winter air temperature and decreasing trend of river ice phenomena might lead to false conclusions (Takács et al., 2012).

The first observations of the water condition and ice cover on the Vistula River (Poland) were made before the official hydrological service was established in the nineteenth century. The most important studies of the conditions and space-time diversity of ice season effects on the Vistula River include works by Lambor (1959), Gołek (1964), Majewski (1987) and Grześ (1991). The data shows that there have been spectacular changes in the duration of ice phenomena and ice cover in Torun since the $19^{\text {th }}$ century (Table 1 ).

The average decrease in the parameters of ice phenonema of the Vistula River in Torun given in Table 1 are typical of the rivers and lakes of the northern hemisphere (Kuusisto and Elo, 1998; Yoo and D'Odorico, 2002). According to Magnuson et al. (2000), over the last 150 years the start date of the ice cover build-up for rivers (e.g. the Mackenzie and Angara) and lakes (e.g. Lake Suva) has been delayed by 5.8 days/100 years, on average, whereas the date of disappearance of ice phenomena 
Table 1. Changes in selected parameters for ice seasons on the Vistula River in Torun (Pawłowski, 2009); $D_{\text {IC }}$ is the total number of days with the river covered by ice during a winter season; $\mathrm{D}_{\mathrm{IP}}$ is the total number of days with any form of ice on the river (border ice, frazil pans, ice cover, ice floe); the description of various ice forms is given in following paragraphs.

\begin{tabular}{|l|c|}
\hline $\begin{array}{l}\text { Parameter } \\
\text { (ice phenomena: 1861-2003, ice cover: 1814- } \\
\text { 2003) }\end{array}$ & $\begin{array}{c}\text { Change } \\
\text { (days/100 years) }\end{array}$ \\
\hline Duration of the ice phenomena ( $\left.\mathrm{D}_{\mathrm{IP}}\right)$ & -34 \\
\hline Start date & 19 \\
\hline End date & -11 \\
\hline Duration of the ice cover $\left(\mathrm{D}_{\mathrm{IC}}\right)$ & -39 \\
\hline Start date & 13 \\
\hline End date & -8 \\
\hline
\end{tabular}

has been 6.5 days/100 years earlier than previously. The main reason for this is the increase of the annual mean air temperature, estimated at $1.2^{\circ} \mathrm{C} / 100$ years, on average, which is particularly apparent in the cold half-year.

Change in the duration of the ice cover in Torun given in Table 1 is much greater than in other rivers and lakes reported above. We believe that the ice regime of the Vistula River in Torun has changed as a result of both natural processes (such as climate change) and anthropogenic processes. Therefore, the objective of this work was to study the air temperature-river ice duration relationship and the influence of anthropogenic factors on this relationship on a Vistula River in Torun. The study is based on a long data series (1882-2011).

\section{STUDY AREA}

Torun is located on the Lower Vistula, on the $735^{\text {th }}$ kilometre of the river. River basin area covers $181033 \mathrm{~km}^{2}$, average river discharge in Torun is about $900 \mathrm{~m}^{3}$. Along the entire reach of the Lower Vistula River, the maximum water levels are the result of ice jam flood events. The levels have been confirmed with flood marks (Grześ and Pawłowski, 2012). In Toruń, there was a series of catastrophic floods of this type from the fourteenth to the nineteenth century (Cyberski et al., 2006). According to Mikulski (1965), Torun has the oldest existing water level records, dating back to the years 1760-1772. The ice seasons there are said to have been examined as early as in the 1720s. River ice regime observations have a longer history on River Daugava (Latwia) where recording started in 1530 (Klavins et al., 2009). Ice conditions can be very different in different locations, even a short distance upstream or downstream from any given location. Therefore, assessments should be conducted on data from river stations that have not been relocated over their period of record (Hodgkins et al., 2005).

The exact date of the use of the first river gauge in Torun is not known. Apparently, in the eighteenth century, a gauging station was placed on a bridge joining Mostowa Street with Bazarowa Island on the left bank of the river. In 1898 the river gauge was mounted in the place where it is today (Fig. 1). It has always been within the proper centre of the city (Pawłowski, 2009).

\section{Ice cover development}

Ice cover on the Lower Vistula River is formed by the frontal progression of mobile forms of ice, so-called frazil pancakes (also visible in Fig. 1C). In the progression phase of the ice cover, there is also border ice and ice bars in shallow parts of the riverbed. Anchor ice is an accumulation of spongy ice or slush adhering to the rocks of a river bed. The rise in water level in the river usually starts in late evening or early morning when the ice begins to form and adheres to the rocks. By late morning, the sun typically warms the river bed sufficiently to release the ice and the water level starts to drop. Surface ice normally forms first along the edges of a river. The ice sheet then builds out from the shore and eventually forms an ice sheet across the entire river (Hodgkins et al., 2005). The generation of frazil during freeze-up is an important ice production process that leads

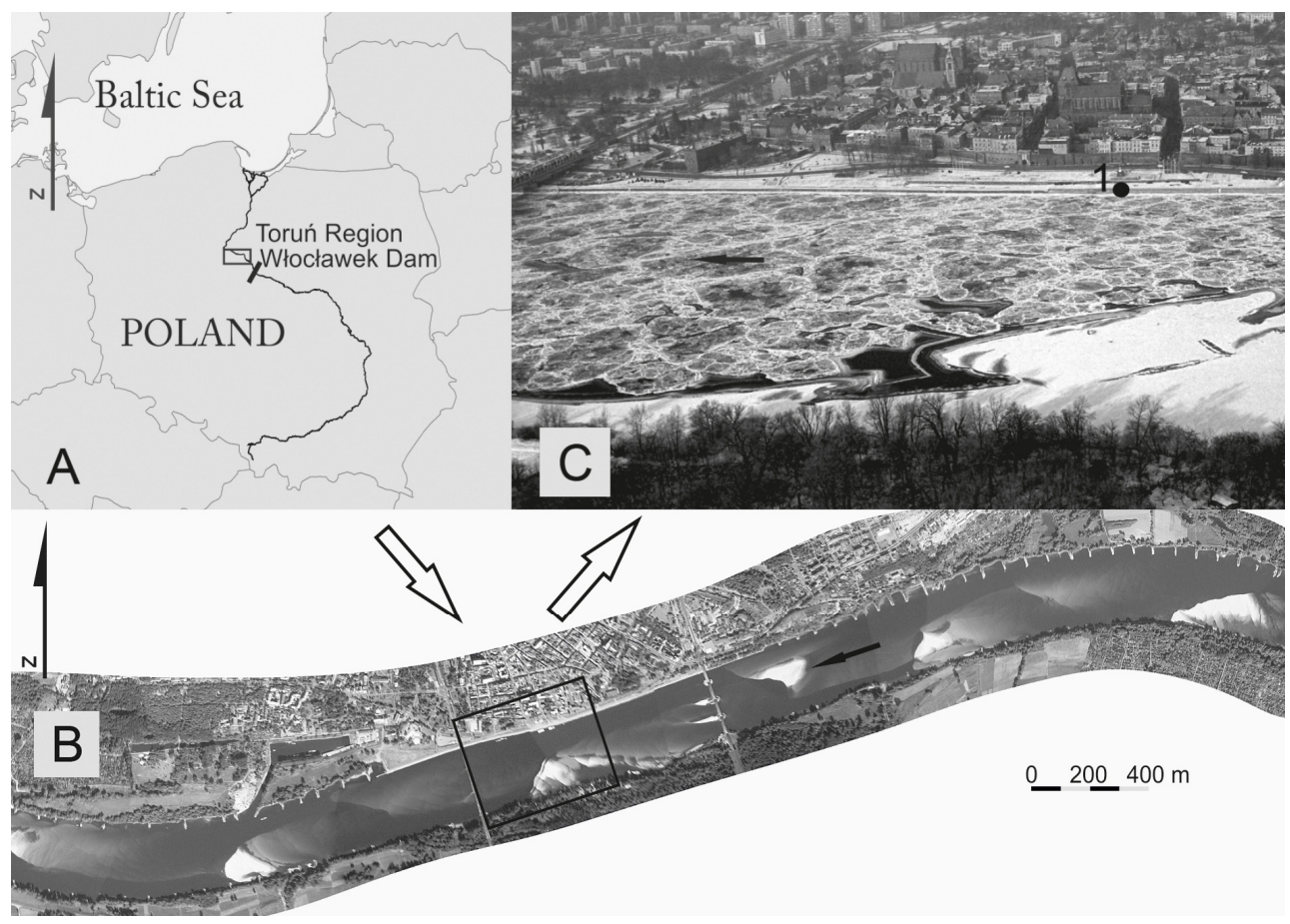

Fig. 1. The location of Torun within Poland (A), the Vistula River in Torun (B) and ice cover on $25^{\text {th }}$ January 1996 (C), with the location of the gauging station (1). Photo by B. Pawłowski. 
to the formation of an ice cover. In regulated rivers, where longitudinal gradients in water temperature exist, this phenomenon gives rise to the typical ice production sequence: frazil discs - frazil flocs - ice pans - solid ice with frazil accumulation. Ice floes are the primary building block of a stable ice cover (Anders, 1995). There is still some controversy about the creation of ice nuclei in rivers. The formation of frazil floes is one of the least well described processes. Frazil crystals conglomerate and continue to grow until they form ice pans of one to several meters diameter. In general, ice floes are oval in shape and possess a fringe of crushed ice on their rims, which probably originates from collisions between individual ice pans. The ice pans float down-river, while being subject to collisions with each other and occasional breaking-up as a consequence. If a river offers some natural or man-made obstruction for the drift, advected ice pans become blocked and the juxtaposed ice cover grows upriver against the flow direction of the river (Boehrer et al., 2004). Drift ice and juxtaposed ice covers have been known from other rivers, e.g. the North American and Central and North European rivers (St. Lawrence River, lower Missouri, Elbe, Odra, Danube). Juxtaposition may also be influenced by ice concentration and flow speed. Grześ and Pawłowski (2012) reported the Vistula River ice cover frontal upriver progression speeds of 10-35 km/day; similar values have been listed by other authors (e.g. Michel, 1971). The natural breakdown of the ice cover initiates the spring snowmelt high water, and may be accompanied by ice jams. On the basis of the historical material and the results of contemporary observations, it has been shown that ice jams and the floods caused by them, despite their transitory character, have been an important and, as yet, poorly known element of the hydrological regime of the Lower Vistula (Cyberski et al., 2006). The complexity of the causes of their origin, the complicated mechanisms of their formation and break-up, the short duration of their existence, as well as other characteristics make them difficult to study (Grześ, 1991).

\section{Anthropogenic factors}

From 1882 until 2011, changes in the ice phenomena on the Vistula River in Torun were driven by two major anthropogenic factors: river control, and the construction of the Włocławek Dam.

\section{Control of the lower Vistula River}

Transverse profiles of the non-controlled riverbed are irregular and shallow. Drops in the longitudinal profile and sandbars disturb and hinder the ice flow. To avoid these problems, the riverbed should have stable cross-sections at characteristic water levels and mild bends. In order to achieve these objectives, river engineering is designed to concentrate the current, stabilise the riverbanks and straighten sharp curves in the riverbed. River regulation changes the morphological parameters of the river bed: the aim is to create better navigational conditions and stream gradient to prevent river ice congestion. The result of river training should be to reduce the duration of ice-covered season and also to lessen the frequency of freeze-up occurrence. The main purpose of the work conducted on the Vistula River in Torun was to reduce the risk of ice jam flooding.

The first instance of human influence on the stretch of the Vistula River in Torun was an attempt to control the river in the territory annexed by Prussia in the second half of the 19th century. Intense works started after 1880 and were completed around 1892. A number of supplementary structures were also constructed, which were finished in 1907. The riverbed width was set at $375 \mathrm{~m}$ and the depth at an average of $1.67 \mathrm{~m}$ for the low water level (Makowski, 1998). The riverbed of the Lower Vistula River along the stretch between Silno and the mouth (941.5 km) was stabilised by more than 2,900 groins (Fig. 2).

After the work was completed, the area of the water table gradually dropped. Moreover, ice production (and therefore the potential amount of ice which could be involved in an ice jam) was also reduced. The higher flow rate also hindered the formation of frazil (on the frontal ice cover progression), and shortened the decay phase of the ice cover. The increased depth of the now-controlled riverbed reduces the likelihood of ice bridges forming, which may contribute to relative frequency of freeze-up.

According to a study conducted by the Department of Hydrology and Water Management of the Nicolaus Copernicus University (DH\&WM NCU) in Torun, the controlled section of the riverbed fills with ice and frazil ice to a lesser degree, and ice jams occur several times less often than in the noncontrolled section of the river (Grześ and Pawłowski, 2012).

\section{Construction of the Wtoctawek Dam}

Not only the regulation works, but also hydropower production changes the features of the river bed and the ice regime. Upstream of the barrage, the flow conditions are changed: the flow velocity and turbulence are low. This is favourable for river ice appearance and freeze-up. Downstream of the dam, turbulence and flow velocity increase, and this hinders ice appearance. Furthermore, at low water stages in winter drift-ice is

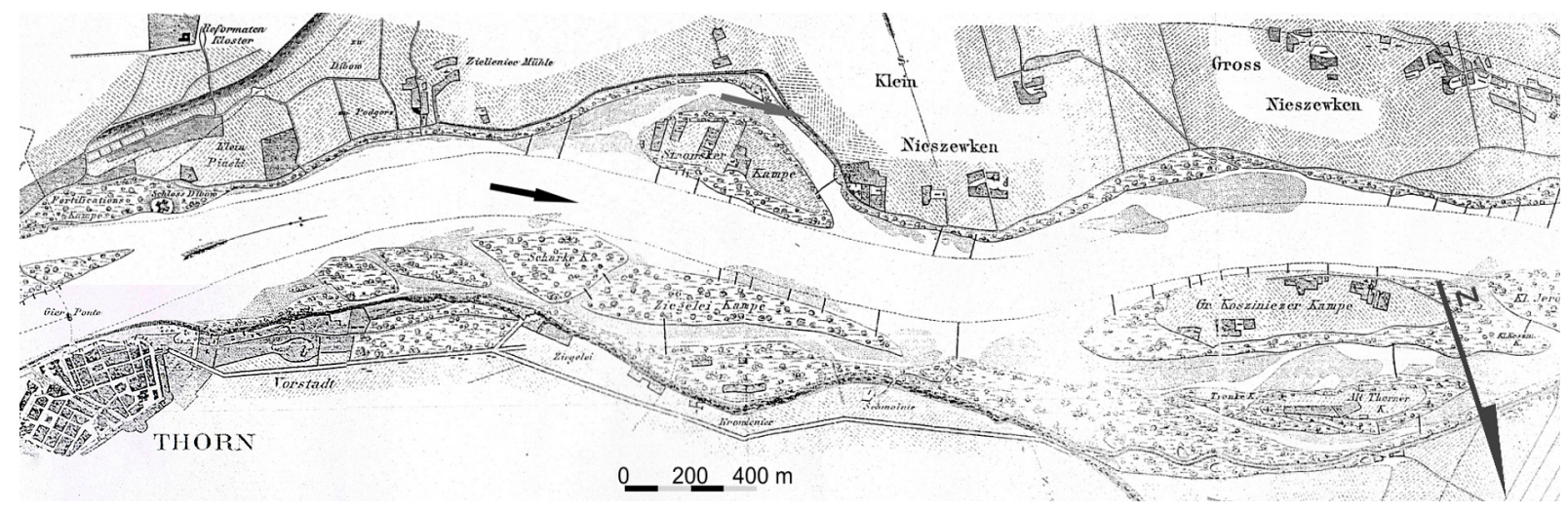

Fig. 2. The Vistula Riverbed in Torun region during river engineering (from the archive DH\&WM NCU). 
restrained so ice-free water may flow through the turbines, and there is only local ice formation (Horvath, 1960). Since the 1970s, the Vistula River has been largely influenced by the Włocławek Dam. Water reserevoir formed by the Włocławek Dam is the largest artificial reservoir in Poland by its area (70.4 $\mathrm{km}^{2}$ ) and the second largest by its capacity (387.2 million $\left.\mathrm{m}^{3}\right)$. It is $59 \mathrm{~km}$ long and has an average width of $1.2 \mathrm{~km}$. Water from the reservoirs is used in the largest hydroelectric power station in the country (capacity 160.2 MW). The reservoir does not play a significant role as a retention reservoir against flooding, and is the only existing part of the planned Lower Vistula River Cascade. The bed scour that has developed downstream of the dam presently reaches Torun. Peak demand from the power plant triggers short-term variations in the water discharge; hourly fluctuations reach $160 \mathrm{~km}$ down the river (Babiński and Habel, 2013). Variations in the water level hinder the formation of ice cover and may lead to breakup of the ice cover and ice run (e.g. from border ice), resulting in downstream ice jams. Additionally, the areas adjacent to the upstream section of the reservoir are exposed to flooding due to ice jams (Grześ, 1991). Both the reservoir and the dam hold most of the debris and suspended matter, as well as the ice flowing down the river. According to Lambor (1959), the suspended matter is a factor in the build-up of frazil ice, as it supplies nuclei for the crystallisation of ice formed in the river's currents, in the progression phase of the ice cover development. As a consequence of the Włocławek Dam flowing frazil ice can be observed more rarely in Torun.

\section{DATA SERIES AND METHODS}

This study uses data series for $\mathrm{D}_{\mathrm{IP}}$ and $\mathrm{D}_{\mathrm{IC}}$ (definitions in Table 1) for the Vistula River in Torun, obtained mainly from the Institute of Meteorology and Water Management (IMiGW), for the period 1882-2011 (Fig. 3). Monthly air temperature data for Toruń, covering the period 1881-2005 (Przybylak et al., 2012) is also used. Data for 2006-2011 was supplemented with data from the public database available at <www.tutiempo.net>. Temperature of the winter season $\left(\mathrm{T}_{\mathrm{WS}}\right)$ was calculated as an average of the three-month means from December to February and is labeled DJF in this study (Kundzewicz and Huang, 2010). The last characteristic used in the study is duration of ice pans (IP), i.e. the total number of days with frazil and ice pan drift.The aim of the study was to identify the contribution of individual factors to change in the ice regime of the Vistula River in Torun and determine their impact on the duration of $\mathrm{D}_{\mathrm{IP}}$ and $\mathrm{D}_{\mathrm{IC}}$. Increasing average winter temperature suggests that the occurrence of ice phenomena would be expected to decrease. To exclude the effect of rising air temperature and to see the potential effect of the particular anthropogenic impacts, the ice regime of years with similar winter thermal forcing (i.e. similar mean winter air temperature) before and after the incidence of the corresponding non-natural impact should be compared (Takács et al., 2012). The study was made for three periods of different hydrodynamic conditions in the Vistula River:

1882-1907 (Period 1); prior to completing river engineering and shaping a new riverbed

1908-1969 (Period 2); controlled river before the construction of the Włocławek Dam

1970-2011 (Period 3); controlled river after the construction of the Włocławek Dam

Analysis of variance was performed to evaluate whether the $\mathrm{D}_{\mathrm{IP}}$ and $\mathrm{D}_{\mathrm{IC}}$ in the studied periods are statistically similar or significantly different. ANOVA is a parametric method for means comparison of several groups. If the p-value is larger than the significance level $(0.05)$, rejection of the the null hypothesis fails because there is not enough evidence to conclude that the population means are different.

To test the effects of river engineering and Włocławek Dam on the Vistula river ice regime in Torun, 12 winters from each period were selected manually.

The average number of ice-covered $\left(\mathrm{D}_{\mathrm{IC}}\right)$ and ice-affected days $\left(\mathrm{D}_{\mathrm{IP}}\right)$ and the incidence rate of ice-cover and river ice appearance were calculated for each period, and the results were compared. The correlation between the ice occurrence $\left(\mathrm{D}_{\mathrm{IP}}\right.$ and $\mathrm{D}_{\mathrm{IC}}$ ) and $\mathrm{T}_{\mathrm{WS}}$ was established. Appointed mathematical relations between winter season temperature and duration of ice phenomena and ice cover were used to calculate $D_{\text {IP }}$ and $D_{\text {IC }}$ for the value of the temperature $\mathrm{T}_{\mathrm{WS}}=-2^{\circ} \mathrm{C}$ (for cold winter season) and $\mathrm{T}_{\mathrm{WS}}=0^{\circ} \mathrm{C}$ (warm winter season).

Icebreaking activity has been carried out on the Vistula River since the end of the nineteenth century. It begins at the river mouth, so that the ice floe can easily float to the sea (Wrycza, 1998). As a result of icebreaking, the natural ice cover duration is reduced. Icebreaking operations were conducted on the Vistula River in Torun on several occasions during the analysed period (for example, in March 1996). The data on $\mathrm{D}_{\text {IC }}$ for these seasons were omitted when determining the correlation with $\mathrm{T}_{\mathrm{Ws}}$.

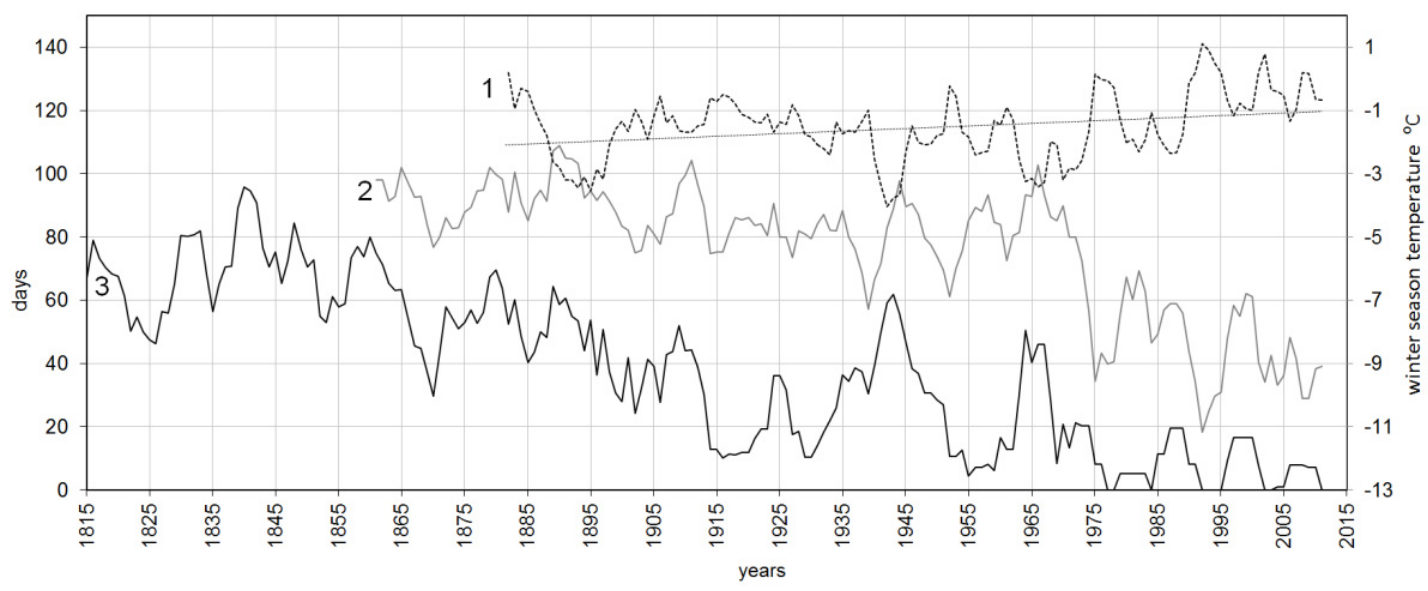

Fig. 3. Variations of the: 1- $T_{W S}$ - winter season temperature (1882-2011), 2 - $D_{I P}$ - duration of ice phenomena (1861-2011), 3 - $D_{I C}-$ duration of ice cover (1815-2011) on the Vistula River in Torun in five-year moving averages. For $\mathrm{T}_{\mathrm{Ws}}$ a linear trend line is added. 


\section{RESULTS}

Selected winters, with a mean temperature between -4.3 and $1^{\circ} \mathrm{C}$ are shown in Table 2 .

Analysis of variance (ANOVA) was performed (Table 3).

ANOVA confirmed significant differences in the course DIC and DIP between analysed periods. This is specially true for DIP, less so for DIC.

Duration of ice phenomena during the study period decreased from the maximum of 136 days in 1909 to just 2 days in 2007, while ice cover decreased from 100 days (1964) to seasons without any ice cover (Fig. 3). Until a few dozen years ago, ice cover was frequently seen on the Vistula River in Torun (Pawłowski, 2009).
In each of the three periods, a different relation between the duration of the ice phenomena (and ice cover) with the winter season temperature was determined (Fig. 4).

Average duration of ice phenomena and ice cover for all periods and the duration calculated from the formulas given in Figure 4 are summarised in Table 4.

In the years 1882-1907 (Period 1), prior to completing river engineering and shaping a new riverbed, ice phenomena and ice cover in Torun lasted longest (Fig. 4A). In the selected winters the average $\mathrm{D}_{\text {IP }}$ value was 88 days and 40 days for $\mathrm{D}_{\mathrm{IC}}$. Within 26 years, in Torun there were five winter seasons recorded without ice cover. In the 12 selected winters ice cover occurred in 9 winters.

Table 2. Characteristics of selected winters in Torun.

\begin{tabular}{|c|c|c|c|c|c|c|c|c|c|c|c|}
\hline \multicolumn{4}{|c|}{ Period 1 (1882-1907) } & \multicolumn{4}{|c|}{ Period 2(1908-1969) Period 3 (1970-2011) } \\
\hline Years & $\mathrm{T}_{\mathrm{WS}}$ & DIP & DIC & Years & $\mathrm{T}_{\mathrm{WS}}$ & DIP & DIC & Years & $\mathrm{T}_{\mathrm{WS}}$ & DIP & DIC \\
\hline 1907 & $-4,3$ & 112 & 76 & 1924 & $-4,2$ & 109 & 88 & 1987 & $-4,3$ & 92 & 41 \\
\hline 1897 & $-3,6$ & 104 & 88 & 1917 & $-3,6$ & 104 & 55 & 2003 & $-3,7$ & 68 & 0 \\
\hline 1889 & $-3,1$ & 120 & 80 & 1912 & $-3,2$ & 74 & 49 & 1982 & $-3,1$ & 83 & 0 \\
\hline 1883 & $-2,1$ & 127 & 85 & 1960 & $-2,1$ & 95 & 51 & 1997 & $-2,1$ & 65 & 38 \\
\hline 1887 & -2 & 91 & 44 & 1945 & -2 & 69 & 52 & 1980 & $-1,9$ & 66 & 0 \\
\hline 1894 & $-1,4$ & 66 & 33 & 1968 & $-1,4$ & 76 & 5 & 1976 & $-1,3$ & 80 & 0 \\
\hline 1885 & $-0,7$ & 88 & 45 & 1951 & $-0,8$ & 71 & 12 & 2009 & $-0,9$ & 28 & 0 \\
\hline 1906 & $-0,5$ & 70 & 13 & 1959 & $-0,5$ & 63 & 0 & 1984 & $-0,4$ & 28 & 0 \\
\hline 1902 & $-0,2$ & 68 & 0 & 1923 & $-0,1$ & 65 & 0 & 1993 & 0 & 44 & 0 \\
\hline 1882 & 0,2 & 77 & 12 & 1914 & 0,2 & 62 & 0 & 1973 & 0,1 & 40 & 0 \\
\hline 1898 & 0,3 & 86 & 0 & 1944 & 0,3 & 91 & 0 & 1974 & 0,2 & 35 & 0 \\
\hline 1884 & 1 & 41 & 0 & 1930 & 0,9 & 31 & 0 & 1988 & 1 & 12 & 0 \\
\hline M & $-1,367$ & 87,5 & 39,7 & & $-1,375$ & 75,8 & 26,0 & & $-1,367$ & 53,4 & 6,6 \\
\hline SD & 1,6768 & 25,091 & 35,196 & & 1,6614 & 21,421 & 30,943 & & 1,682 & 25,568 & 15,389 \\
\hline
\end{tabular}

Table 3. Analysis of variance (ANOVA) for checked parameters.

\begin{tabular}{|c|l|r|r|r|r|r|r|}
\hline \multirow{2}{*}{ Parameter } & \multicolumn{1}{|c|}{ Source of Variation } & \multicolumn{1}{c|}{ SS } & \multicolumn{1}{c|}{ df } & \multicolumn{1}{c|}{ MS } & F & p-value & F crit \\
\hline \multirow{3}{*}{ DIP } & Between Groups & 7201,167 & 2 & 3600,5 & 6,2003 & 0,0052 & 3,2849 \\
\cline { 2 - 8 } & Within Groups & 19163,58 & 33 & 580,71 & & & \\
\cline { 2 - 8 } & Total & 26364,75 & 35 & & & & \\
\hline \multirow{3}{*}{ DIC } & Between Groups & 6633,167 & 2 & 3316,5 & 4,0894 & 0,0259 & 3,2849 \\
\cline { 2 - 9 } & Within Groups & 26763,58 & 33 & 811,02 & & & \\
\cline { 2 - 8 } & Total & 33396,75 & 35 & & & & \\
\hline
\end{tabular}

Explanations: SS - sums of squares, df - degrees of freedom, MS - mean square, F - test of equality of variances (the explained variance/the unexplained variance), p-value - the probability of obtaining the observed sample results when the null hypothesis is actually true, F crit the critical value as extracted from the f-distribution.

Table 4. Average duration of ice phenomena and ice cover (days) and calculated for the value of the temperature $\mathrm{T}_{\mathrm{WS}}=-2^{\circ} \mathrm{C}$ and $\mathrm{T}_{\mathrm{WS}}=$ $0^{\circ} \mathrm{C}$.

\begin{tabular}{|c|c|c|c|c|c|c|c|c|c|c|c|c|}
\hline & \multicolumn{4}{|c|}{$\begin{array}{l}\text { Period 1 } \\
(1882-1907)\end{array}$} & \multicolumn{4}{|c|}{$\begin{array}{l}\text { Period 2 } \\
(1908-1969) \\
\end{array}$} & \multicolumn{4}{|c|}{$\begin{array}{l}\text { Period 3 } \\
(1970-2011) \\
\end{array}$} \\
\hline & $-2^{\circ} \mathrm{C}$ & & & $0^{\circ} \mathrm{C}$ & $-2^{\circ} \mathrm{C}$ & & & $0^{\circ} \mathrm{C}$ & $-2^{\circ} \mathrm{C}$ & & & $0^{\circ} \mathrm{C}$ \\
\hline $\mathrm{D}_{\mathrm{IP}}$ & 95 & 88 & $100 \%$ & 72 & 82 & 76 & $86 \%$ & 63 & 62 & 53 & $60 \%$ & 36 \\
\hline $\mathrm{D}_{\mathrm{IC}}$ & 53 & 40 & $100 \%$ & 14 & 37 & 26 & $65 \%$ & 2 & 10 & 7 & $18 \%$ & 0 \\
\hline
\end{tabular}



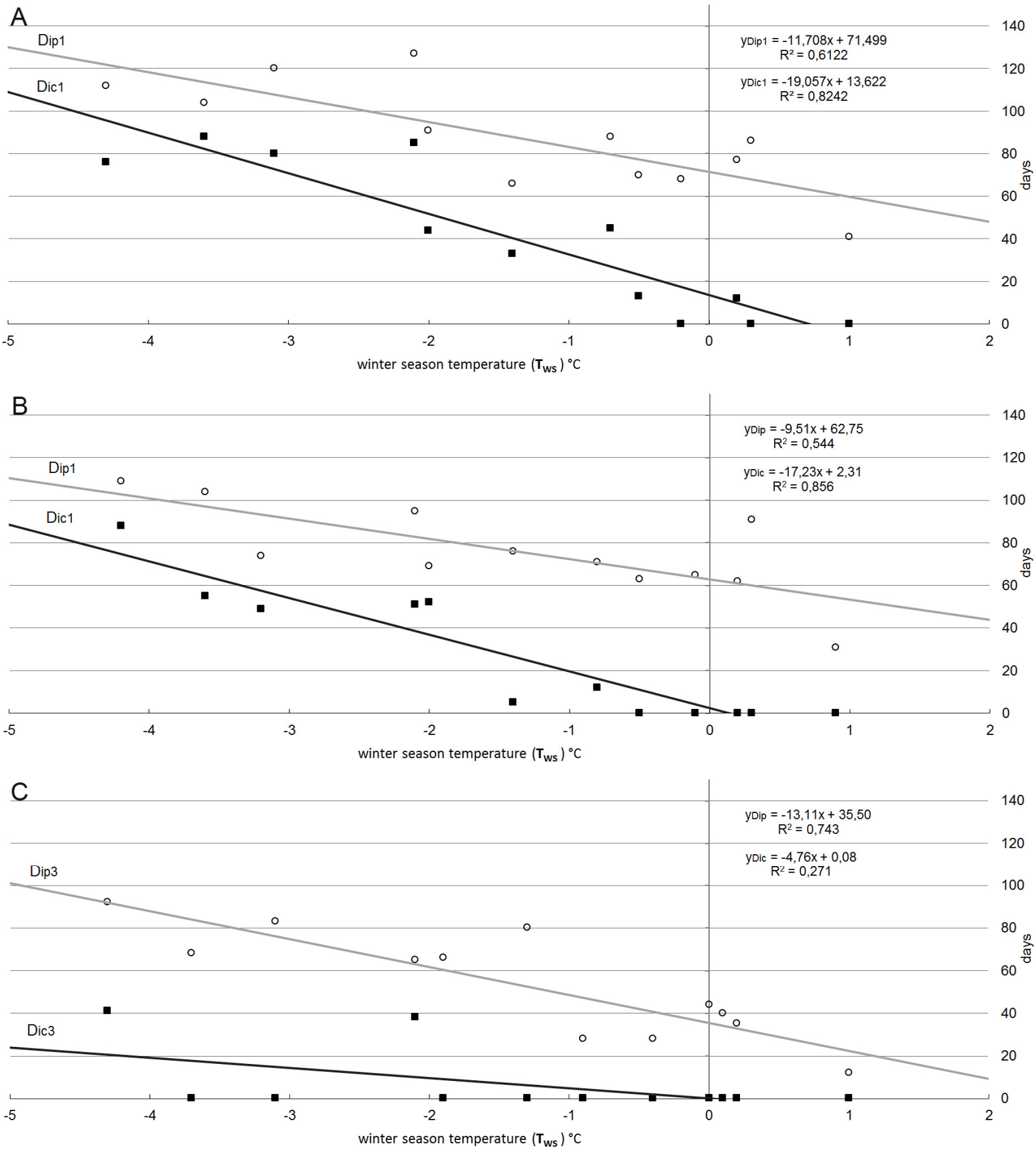

Fig. 4. Relation between the winter season air temperature $\left(\mathrm{T}_{\mathrm{WS}}\right)$ and the analysed parameters in the years: $\mathrm{A}-1882-1907, \mathrm{~B}-1908-1969$, C - 1970-2011.

The second period of 1908-1969 includes the controlled river, but before the construction of the Włocławek Dam (Fig. 4B). In the selected winters the average $\mathrm{D}_{\mathrm{IP}}$ value was 76 days and 26 days for $\mathrm{D}_{\text {IC }}$. Within 62 years, 23 winter seasons without ice cover were recorded in Torun. The increase in the number of such cases was mainly the result of the deeper river channel and the faster flow rate. In the selected winters ice cover occurred in 7 season.

The third analysed period (1970-2011) covers the time from the construction of the Włocławek Dam to the present (Fig. 4C). The average value was 53 days for $\mathrm{D}_{\mathrm{IP}}$ and 7 days for $\mathrm{D}_{\mathrm{IC}}$ in the selected winters. Within 43 years, 33 winter seasons without ice cover were recorded in Torun. In the selected winters ice cover occurred only in 2 season.
As can be concluded from the data, the impact of river engineering and the Włocławek Dam can differ in terms of their intensity and mean winter temperature $\mathrm{T}_{\mathrm{WS}}$. For $\mathrm{D}_{\mathrm{IP}}$, the impact of river engineering on both cold winter seasons $\left(\mathrm{T}_{\mathrm{WS}}=-2^{\circ} \mathrm{C}\right)$, and warm winter seasons $\left(\mathrm{T}_{\mathrm{WS}}=0^{\circ} \mathrm{C}\right)$, shows a similar shortening of their duration (13 days and 9 days, about $13 \%$ for both of parameters) compared to the situation before the regulation. In cold seasons, river engineering reduces $\mathrm{D}_{\text {IC }}$ by 16 days $(30 \%)$. The reduction reached 12 days $(86 \%)$ in warm winter conditions. The construction of the Włocławek Dam in 1970 resulted in further shortening of the duration of ice phenomena. $D_{\text {IP }}$ in the cold winter seasons was shortened by 20 days $(24 \%)$, and in the winter seasons with warm temperature conditions, by up to 27 days (43\%) compared to the baseline values before 
Włocławek Dam construction. After 1970, a greater change in $\mathrm{D}_{\mathrm{IC}}$ was observed, by 27 days $(73 \%)$ for cold $\mathrm{T}_{\mathrm{WS}}$ conditions. Winter season with warm $\mathrm{T}_{\mathrm{WS}}$ conditions, are always without ice cover occurrence. Decreases in the average ice phenomena and ice cover duration are summarized in Figure 5.

Comparing the $\mathrm{D}_{\mathrm{IP}}$ and $\mathrm{D}_{\mathrm{IC}}$ in Torun of the late nineteenth century and at present, $\mathrm{D}_{\mathrm{IP}}$ can be seen to have been shortened by nearly half, and $\mathrm{D}_{\mathrm{IC}}$ almost six-fold. As shown in Figure 5, the construction of the Dam seems to have had a stronger impact on the analysed parameters.

The analysis of the number of days with ice pans (frazil) showed that IP did not change significantly between the first and second period and lasted on the average about 44 days. After construction of the Włocławek Dam (third period), IP has decreased to 41 days in the selected winters.

\section{DISCUSSION}

River ice occurrence and the amount of drift-ice are directly controlled by air temperature. For freeze-up, the role of the morphological parameters of the river bed is also important (Horváth, 1960). River-ice formation and breakup are also influenced by water discharge, temperature and local hydraulic conditions (Beltaos, 1997). The relation between $\mathrm{T}_{\mathrm{Ws}}$ (December-March) and ice cover in the period 1961-2000 for the lakes located in the northern part of the Polish Lowland were presented by Marszelewski and Skowron (2006). The obtained trend lines indicate that the currently observed course of ice phenomena is, in the case of several of the analysed lakes, close to the course of the Vistula River ice cover in the late nineteenth and early twentieth century.

The first analysed period (1882-1907) to which $\mathrm{D}_{\text {IP }}$ and $\mathrm{D}_{\text {IC }}$ were compared in later periods, contained some years during ongoing river engineering works. No $\mathrm{T}_{\mathrm{Ws}}$ data was available for the period before 1882 . The existing series of $D_{I P}$ data (since 1861 ) and $D_{\text {IC }}$ data (since 1814) has already been the subject of studies (Pawłowski, 2009). On the basis of these results it can be concluded that the impact of the control of the river on the shortening of both ice phenomena and ice cover duration in Torun could have been somewhat greater than presented in this article. It results also from data presented in Figure 3, where already after
$1860 \mathrm{D}_{\mathrm{IC}}$ decreased. Since the completion of the river control work, sandy shoals move along the riverbed at an average speed of several hundred meters per year. They cause frequent changes in the transverse shape of the river and greatly hinder water transport (Babiński and Habel, 2013). Shallow places in the riverbed (leading to ice bridges) can also initiate the progression of frontal ice cover.

The construction of the Włocławek Dam significantly reduced the number of days with frazil ice run. As already mentioned, this has to do with the retention of a large part of the suspension carried by the river in the reservoir. This type of influence of the reservoir on the ice cover is also visible in the river reach below Torun. Similar changes of the $\mathrm{D}_{\mathrm{IP}}$ after 1970 were also recorded by Gorączko (2013) in Fordon, over $40 \mathrm{~km}$ downstream of Torun. At present, the relationships beetwen ice cover duration and winter season temperature are not strong on the Vistula River in Torun, $59 \mathrm{~km}$ below the Włocławek Dam. Ice cover occurrence and duration in the third analysed period (1970-2011) did not result only from the course of Tws $\left(\mathrm{R}^{2}=\right.$ 0,271 , Fig. 4C). The Włoclawek Dam has a predominant role. Ice phenomena and ice cover duration has shortened significantly in this period: by $30 \%$ (from 76 to 53 days) a and by $73 \%$ (from 26 to 7 days), respectively.

River engineering impact on the ice regime was analysed on the Danube River in Budapest by Takács et al., (2012); there similar results were obtained. The engineering works on both the Vistula and Danube Rivers were conducted and finished at a similar time. After the works were completed, the duration of ice cover on Danube decreased by more than half while a relative frequency of freeze-up was recorded (at present, on the polluted river, when the freezing point becomes lower, this frequency is $25 \%$ ). The ice phenomena duration on Danube after engineering decreased too.

Hungarian authors also analysed the changes in the ice regime resulting from the construction of the power plant (barrage and reservoir) on the Raba River (Hungary), where results were a little bit different. The most similar to the conditions of the Vistula River in Torun was the Raba reach in the Árpás region. The gauging station is located $39 \mathrm{~km}$ downstream from the barrage at Nick. At Árpás, after the construction of the barrage, the average number of the ice-covered days decreased from 32

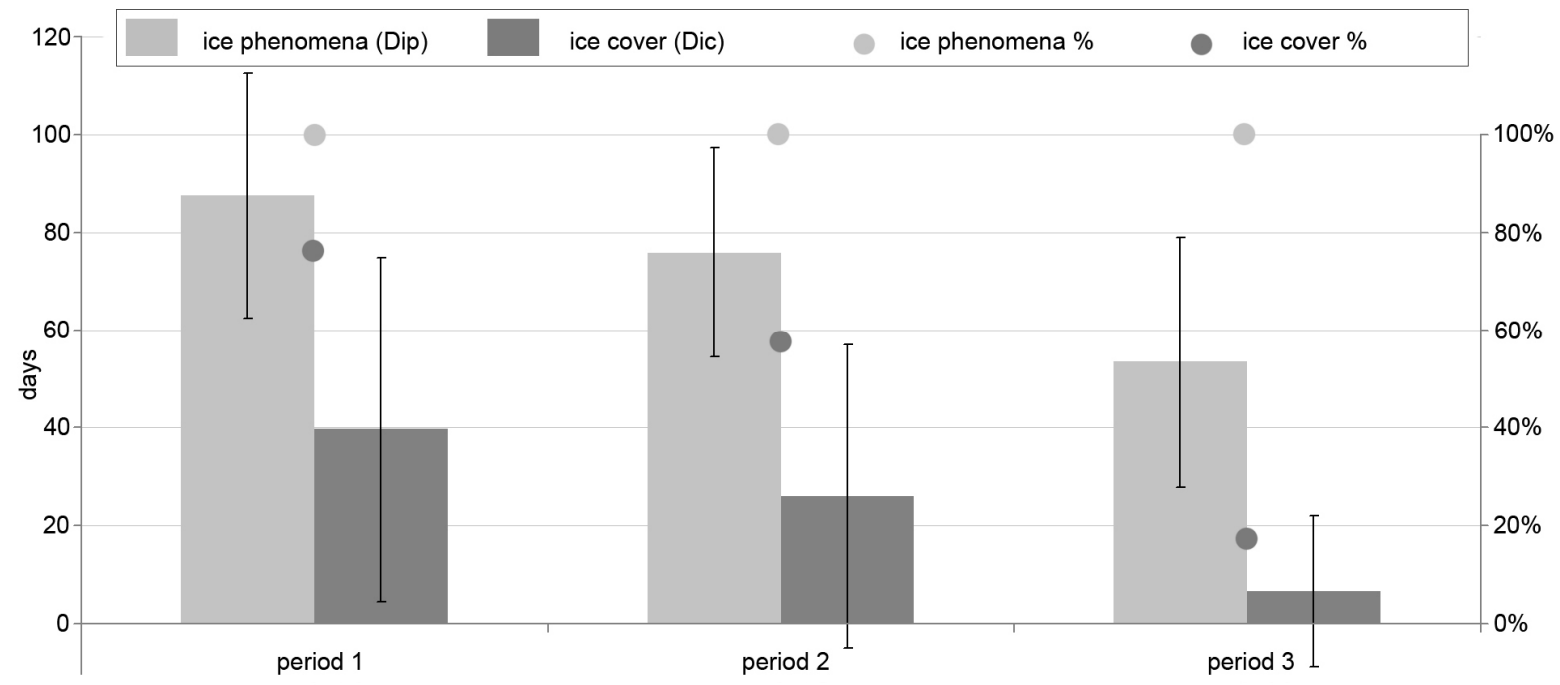

Fig. 5. Average duration of ice phenomena and ice cover with standard deviation and relative frequency of freeze-up and ice occurrence at Torun on the Vistula River in the analysed periods. 
to $25(-22 \%)$, while the ice-affected season (= ice phenomena duration) decreased from 42 to 34 days $(-19 \%)$ in the selected winters. Relative frequency of freeze-up was also slightly reduced (Takács et al., 2012). On the Vistula River in Torun the limited duration of the ice cover after the creation of the barrage in Włocławek was greater.

The average temperature of the winter season increased in the analysed period from $\mathrm{T}_{\mathrm{WS} 1}=-2 \cdot 1^{\circ} \mathrm{C}$ to $\mathrm{T}_{\mathrm{WS} 3}=-1 \cdot 1^{\circ} \mathrm{C}$. The differences in the ice phenomena and cover duration, calculated for $\mathrm{T}_{\mathrm{WS} 1}$ and $\mathrm{T}_{\mathrm{WS} 3}$ values (based on the formulas $\mathrm{D}_{\mathrm{ip} 3}$ and $\mathrm{D}_{\mathrm{ic} 3}$ in Figure 4) are part of the changes to $D_{I P}$ and $D_{\text {IC }}$ resulting from the winter season warming. If there were no changes of winter season temperature, in present, ice cover duration would be about 5 days longer as well as ice phenomena duration would be about 14 days longer on average.

Jiang et al. (2008) analysed data from the Yellow River for period 1968-2001. They concluded that the freeze duration has shortened by 38 days (from 109 to 71 days) at Bayangaole and only by 27 days (from 116 to 91 days) at Sanhuhe, mainly as a result of temperature increase. River on the lower reach froze up in the majority of the winter seasons in the analysed period.

On the stretches of the river below dams, the changes of the duration of ice phenomena are also a result of changes temperature of the water. For example, in the Ropa River in the Polish Carpathians, changes in the physicochemical properties of the water were caused by the Klimkowka Reservoir. After the reservoir had started operations, at a distance of $16 \mathrm{~km}$ below the dam, in November and December the average temperature of water increased by $1.3^{\circ} \mathrm{C}$. The $\mathrm{D}_{\mathrm{IP}}$ on the river below the dam decreased by 21 days on average (Soja and Wiejaczka, 2013). It is similar to the results presented in this paper.

The ice cover duration on the Vistula River in Torun also depends on other factors not analysed here. Among these, the most important role belongs to the water pollution, which probably increased during the analysed period. Some of the water contaminants have an anti-freeze effect, and therefore much colder temperature seems to be needed today to produce the same river ice phenomena as at the beginning of the 20th century. For freeze-up, the dominant factor is the chloride-ion concentration. The most important source of the chloride ion is salt which is used for de-icing roads in winter. In terms of meteorological factors, the volume of the ice produced on the river is not only affected by air temperature, but also cloudiness. As shown by studies carried out in winter 2013, a smaller thickness and durability of ice cover are affected by snowfall occurring during theice cover progression phase (Pawłowski, 2013). The course of ice phenomena also depends on the river discharge. All of these un-analysed conditions have certainly influenced the reduction in the correlation coefficient values shown in Figure 4. According to Majewski (2007), formation of ice cover on flowing waters is a very complex physical process and therefore predicting the time of appearance, character and thickness of ice cover is extremely difficult.

\section{CONCLUSIONS}

Changes in the ice cover ice phenomena duration since the nineteenth century on the Vistula River in Torun have been greater than the changes reported for other rivers. At present, the Vistula ice regime is more a result of anthropogenic factors than climate change.

The following percentage shares of individual factors in reducing the ice phenomena and ice cover duration in Torun were recorded:
- Changes due to river control resulted in a shortening of all of the ice phenomena duration by $14 \%$, and duration of ice cover by $35 \%$,

- Changes caused by the construction of the Włocławek Dam shortened the duration by $26 \%$ for ice phenomena and $47 \%$ for ice cover in comparison to their values from the first analysed period (Table 4).

- Changes also included the frequency of freeze-up (Fig. 5). Currently, ice cover in Torun is formed during cold winter seasons, if the average winter temperature is lower than $-2.0^{\circ} \mathrm{C}$ (Fig. 4C). Its appearance is treated as an extraordinary phenomenon, especially by younger people in the Torun Region. After 1970, the Włocławek Dam has predominant role in Vistula River ice regime in Torun.

The most important changes occur in the duration of the ice cover. The lack of freeze period causes shortening in the ice floes duration too. Anthropogenic factors analysed in this paper did not cause substantial shortening in the number of days with ice pans.

Change in the duration of ice cover is also the result of increased winter season temperature. Similarly to other regions in the northern hemisphere, in the analysed period this increase was about $1.1^{\circ} \mathrm{C}$. Hence, the duration of ice phenomena in Torun was shortened by 14 days, and the ice cover's duration by 5 days.

It is necessary to maintain the river's hydro-engineering structures in good condition to keep the currently observed relations of ice phenomena (ice cover) duration with the mean winter temperature stable. River depth is also a significant factor in the effectiveness of the icebreaking. Currently, some of groins need of renovation or complete reconstruction. Further changes in the course of the Vistula River's ice regime in Torun will certainly be influenced by the construction of another dam of the Lower Vistula River Cascade. This investment is being planned for the section of the Vistula River between Włocławek and Torun.

\section{REFERENCES}

Anders, D.D., 1995. Frazil generation and ice floe formation on a regulated river, 8th Workshop on the Hydraulics of Ice Covered Rivers Kamloops, British Columbia, 59-75. http://cripe.civil.ualberta.ca/Downloads/08th_Workshop/And res_1995.pdf

Babiński, Z., Habel, M., 2013. Hydromorphological conditions of the lower Vistula in the development of navigation and hydropower. Acta Energetica, 2/15, 83-90, doi: 10.12736/issn.2300-3022.2013206.

Beltaos, S., 1997. Onset of river ice breakup. Cold Regions Science and Technology, 25, 183-196.

Boehrer, B., Tibke, M., Suhr, U., 2004. Frontal progression of a juxtaposed ice cover on the Elbe river. Journal of Hydrology, 288, 258-263, doi: 10.1016/j.jhydrol.2003.10.009.

Cyberski, J., Grześ, M., Gutry-Korycka, M., Nachlik, E., Kundzewicz, Z.W., 2006. History of floods on the River Vistula. Hydrological Sciences Journal, 51:5, 799-817, doi: 10.1623/hysj.51.5.799.

Gołek, J., 1964. Ice phenomena on the Polish rivers. Works of State Hydrological-Meteorological Institute, 63. (In Polish.)

Goraczko, M., 2013. Variability of ice phenomena on the Vistula River in the vicinity of Bydgoszcz. Scientific Review Engineering and Environmental Sciences, 62, 382-388. (In Polish.) 
Grześ, M., 1991. Ice jam and floods on the lower Vistula River. Mechanism and processes, Institute of Geography and Spatial Organization, Polish Academy of Science, Warsaw. (In Polish.)

Grześ, M., Pawłowski, B., 2012. Hydromorphological conditions of ice-breaking on the Vistula River from Włocławek Barrage to the river mouth, taking into account the winter season of 2011/2012. Regional Board of Water Management, Gdańsk (In Polish.)

Hattermann, F.F., Kundzewicz, Z.W., Huang, S., Werner, P., 2013. Climatological Drivers of Changes in Flood Hazard in Germany. Acta Geophysica, 61, 463-477, doi: 10.2478/s11600-012-0070-4.

Hodgkins, G.A., Dudley, R.W., Huntington, T.G., 2005. Changes in the number and timing of days of ice-affected flow on northern New England rivers, 1930-2000. Climatic Change, 71, 319-340, doi: 10.1007/s10584-005-5926-z.

Horváth, S., 1960. A csatornázás hatása a magyar Duna jégjárására. [The effects of river channeling on river ice regime]. Vízügyi Közlemények, 42/4, 527-570. (In Hungarian.)

http://www.ipcc.ch/publications_and_data/ar4/syr/en/spms1.html

Hurrell, J.W., 1995. Decadal trends in the North Atlantic oscillation: regional temperatures and precipitation. Science, 269, 5224, 676-679, doi: 10.1126/science.269.5224.676.

Jiang, Y., Dong, W., Yang, S., Ma, J., 2008. Long-term changes in ice phenology of the Yellow River in the past decades. Journal of Climate, 21, 4879-4886.

Klavins, M., Briede, A., Rodinov, V., 2009. Long term changes in ice and discharge regime of rivers in the Baltic region in relation to climatic variability. Climatic Change, 95, 485498.

Kuusisto, E., Elo, A.-R., 1998. Lake and river ice variables as climate indicators in Northern Europe. Internationale Vereinigung fur Theoretische und Angewandte Limnologie, Verhandlungen, 2761-2764.

Kundzewicz, Z.W., Huang, S., 2010. Seasonal Temperature Extremes in Potsdam. Acta Geophysica, 55, 1115-1133, doi: 10.2478/s11600-010-0026-5.

Lambor, J., 1959. Ice phenomena on inland waterways in Poland. Works and Studies of the Committee of the Water Management, Hydrological Works. II, 1, 121-138. (In Polish.)

Magnuson, J.J., Robertson, D.M., Benson, B.J., Wynne, R.H., Livingstone, D.M., Arai, T., Assel, R.A., Barry, R.G., Card, V., Kuusisto, E., Granin, N.G., Prowse, T.D., Stewart, K.M., Vuglinski, V.S., 2000. Historical Trends in Lake and River Ice Cover in the Northern Hemisphere. Science, 289, 5482, 1743-1746, doi: 10.1126/science.289.5485.1743.

Majewski, W., 1987. Influence of ice cover on the characteristics of run-of-river reservoirs on lowland rivers on the example of Włocławek Reservoir. Institute of Hydro-Engineering, Gdańsk. (In Polish.)

Majewski, W., 2007. Flow in open channels under the influence of ice cover. Acta Geophysica, 55, 11-22, doi: 10.2478/s11600-006-0041-8.
Makowski, J., 1998. Floodbanks of the Lower Vistula: historical forming, current state, work in the time of large swelling of the river. Vol. 2. Institute of Hydroengineering of Polish Academy of Sciences, Torun - Biała Góra. (In Polish.)

Marszelewski, W., Skowron, R., 2006. Ice cover an indicator of winter air temperature changes: case study of the Polish Lowland lakes. Hydrological Sciences Journal, 52, 336-349.

Michel, B., 1971. Winter regime of rivers and lakes. Cold regions research and engineering laboratory. Corps of Engineers NTIS, Springfield, VA, USA.

Mikulski, Z., 1965. About oldest systematic observation of gauge height of water level on Polish land. Review of Geophysics, 10, 2, 153-169. (In Polish.)

Paromov, V.V, Shantykowa, L.N., 2010. Change of ice regime characteristics on the rivers in the Upper Yenisei basin. Ice and Snow, 2 (110), 51-55. (In Russian.)

Pawłowski, B., 2009. Long-Term variability in the course of ice phenomena on the Vistula River in Torun, Bulletin of Geography. Nicolaus Copernicus University, Physical Geography Series, 1, 91-102.

Pawłowski, B., 2013. The course of the ice phenomena on the Lower Vistula in the winter 2013, on the stretch upper Włocławek Reservoir. Water Management, 11, 420-423. (In Polish.)

Prowse, T.D., Beltaos, S., 2002. Climatic control of river-ice hydrology: a review. Hydrol. Process., 16, 805-822, doi: 10.1002/hyp.369.

Przybylak, R., Maszewski, R., Pospieszyńska, A., 2012. The influence of atmospheric circulation on extreme values o air temperature in the Bydgosko-Toruński Region in the period 1881-2005. Role of the circulation of the atmosphere in the forming of the climate, Silesian University, 217-236.

Smith, L.C., 2000. Trends in Russian Arctic river-ice formation and breakup, 1917 to 1994. Physical Geography, 21, 1, 4656.

Soja, T., Wiejaczka, Ł., 2013. The impact of a reservoir on the physicochemical properties of water in a mountain river. Water and Environment Journal, doi:10.1111/wej.12059

Takács, K., Kern, Z., Nagy, B., 2012. Impacts of anthropogenic effects on river ice regime: Examples from Eastern Central Europe. Quaternary International, 1-8, http://dx.doi.org/10.1016/j.quaint.2012.12.010.

Wrycza, T., 1998. Ice-breaking. Monolit, Gdańsk - Gdynia. (In Polish.)

www.tutiempo.net

Yoo, J., D’Odorico, P., 2002. Trends and fluctuations in the dates of ice break-up of lakes and rivers in Northern Europe: The effect of the North Atlantic Oscillation. Journal of Hydrology, 268, 100-112.

Received 2 June 2014 Accepted 23 December 2014 